\title{
Variations of Bacterial Populations in Human Faeces Measured by FISH with Group-Specific 16S rRNA-Targeted Oligonucleotide Probes
}

\author{
Gjalt W. Welling, ${ }^{*}$ Linda Wildeboer-Veloo, Gerwin C. RaAngs, Alison H. Franks, Gijsbert J. Jansen, \\ Rudi H.J. Tonk, John E. Degener and Hermie J.M. HARMSEN
}

Department of Medical Microbiology, University of Groningen, Hanzeplein 1, 9713 GZ Groningen, The Netherlands

Received for publication, December 15, 1999

The human intestinal tract contains a complex ecosystem consisting mainly of obligatory anaerobic bacteria, usually referred to as the normal flora. The composition of this flora plays an important role in human health and disease. To measure the effect of treatments aimed at modulating the normal flora, we have developed fluorescent 16S rRNA targeted oligonucleotide probes for numerically important groups of bacteria in the human intestine. These probes have been used for whole cell fluorescent in situ hybridization (FISH) to study the composition of the human intestinal flora over time. To facilitate detection and enumeration, we have combined FISH with automated microscopic image analysis. Measurement of 48 samples can be done overnight. In this study we have focused on the number of bifidobacteria present in faecal samples of different age groups. The percentage bifidobacteria in faeces ranges from 0 to $78.9 \%$ depending on the age group. In each age group large variations were found. In faecal samples from formula-fed newborn infants we found individual differences ranging from 0 to $54.1 \%$ bifidobacteria and in faecal samples from elderly (77$91 \mathrm{yr}$ ) individual differences ranged from 0.2 to $41.3 \%$.

Key words: FISH; anaerobic microflora; 16S rRNA probes; automated counting

\section{INTRODUCTION}

The human intestinal tract contains a complex ecosystem consisting mainly of obligatory anaerobic bacteria, usually referred to as the normal flora $(3,11)$. The composition of this flora plays an important role in human health and disease $(5,7,13,20)$. To understand the effects of treatments aimed at modulating the normal flora, accurate means for enumeration of the various bacterial populations are required. Conventional methods rely on cultivation of bacteria on selective media. However, many bacteria are difficult to culture or are unculturable, and often media are not truly specific $(17,19)$. Advances in the field of molecular phylogeny have made it possible to study bacterial populations by a culture-independent approach (2). Crucial for this was a ribosomal constituent: the $16 \mathrm{~S}$ ribosomal RNA (16S rRNA). Each bacterial cell contains 10,000-60,000 ribosomes containing 16S rRNA and this means that detection of bacteria is facilitated using fluorescent in situ hybridization (FISH) with fluorescent oligonucleotide probes targeted at $16 \mathrm{~S}$ rRNA $(1,2,6,9)$. Probes have been developed directed

*Corresponding author. Mailing address: Department of Medical Microbiology, University of Groningen, Hanzeplein 1, $9713 \mathrm{GZ}$ Groningen, The Netherlands. Phone: +31-50-363-3513. Fax: +31-50-363-3528. at different phylogenetic levels (Domain, Family, Genus, Species) of the bacterial Kingdom and new probes are being developed with which it is possible to identify quantitatively a large number of different bacterial species of the gut ecosystem $(1,4,8,14,15)$. These probes were used to study variations in bacterial populations in the human intestinal tract. A well-studied genus in the gastrointestinal tract is the genus Bifidobacterium (16). Bifidobacteria are numerically important in the gastrointestinal tract and their health-related properties are widely appreciated (18). In this study we will focus on the variations in the number of bifidobacteria in faecal samples of human volunteers. The changes over a period of 200-220 days were studied in adult volunteers and those in new-born infants were studied during the first 15-21 days of life. In addition, the percentage bifidobacteria in different age groups was determined. To facilitate detection and enumeration, we have combined FISH with automated microscopic image analysis (12).

\section{MATERIALS AND METHODS}

\section{Faecal Samples from Newborn Infants}

Faeces from newborn breast-fed and formula-fed infants was collected during the first 15-21 days of life. The faecal samples were fixed, using $0.5 \mathrm{ml}$ sample in $0.5 \%$ cysteine- $\mathrm{HCl}$ storage buffer and $4.5 \mathrm{ml}$ freshly 
prepared 4\% paraformaldehyde in PBS. For this, $2 \mathrm{~g}$ paraformaldehyde is added to $30 \mathrm{ml}$ Milli-Q followed by $100 \mu \mathrm{l}$ of $1 \mathrm{~m} \mathrm{NaOH}$. The solution is heated until handwarm (about $50^{\circ} \mathrm{C}$, microwave) and the paraformaldehyde is dissolved slowly by gentle shaking. Next, $16.6 \mathrm{ml}$ of 3-times concentrated PBS is added. The $\mathrm{pH}$ of the solution is adjusted to $\mathrm{pH} 7.2$ and the volume is adjusted to $50 \mathrm{ml}$ with Milli-Q. The solution is filtered through a $0.2 \mu \mathrm{m}$ filter and stored at $5^{\circ} \mathrm{C}$. The solution should be used within 5 days. The fixed faecal samples were stored at $-80^{\circ} \mathrm{C}$.

\section{Faecal Samples from Adult Volunteers over an 8-Month} Period and Single Samples from Different Age Groups

A group of healthy volunteers $(n=9)$ ranging from 24 to 52 years provided fresh faecal samples twice a month for an 8-month period. In addition, faecal samples were collected from healthy volunteers (children and adults) who were not restricted in their normal western European diet and did not take antibiotics or other drugs known to influence the faecal flora composition for at least 4 weeks prior to sampling. The different age groups were: a group of children aged 2-3 years, a group of adults (20-52 years) and a group of elderly ranging in age from 77-91 years.

Portions $(0.5 \mathrm{~g})$ of each stool were suspended in 4.5 $\mathrm{ml}$ filtered $(0.2 \mu \mathrm{m}$ pore size) PBS and vortexed with a few glass beads ( $4 \mathrm{~mm}$ diameter) for at least $3 \mathrm{~min}$ to homogenize the sample. The suspension was centrifuged at $700 \times g$ for $1 \mathrm{~min}$ to remove debris. From the supernatant $1 \mathrm{ml}$ was fixed in $3 \mathrm{ml}$ freshly prepared $4 \%$ paraformaldehyde. After overnight fixation at $4{ }^{\circ} \mathrm{C}$ the cells were stored in aliquots at $-80^{\circ} \mathrm{C}$ until use. After thawing and careful mixing of the suspension, cells were diluted in 5\% Tween-80. Suitable dilutions (e.g. $160 \times$ for hybridization with the Bif 164 probe) were applied to custom-made slides with square-shaped wells $(1 \times 1$ $\mathrm{cm})$. Slides were pretreated by soaking them in $0.1 \%$ gelatin, $0.01 \% \mathrm{KCr}\left(\mathrm{SO}_{4}\right)_{2} \cdot 12 \mathrm{H}_{2} \mathrm{O}$ for $30 \mathrm{~min}$ at room temperature. Ten microliters was applied to each well and carefully spread over the total surface. After drying at room temperature, slides were fixed for $10 \mathrm{~min}$ in $96 \%$ ethanol. The slides with the fixed cells were kept in a dry atmosphere at room temperature until use.

\section{OLIGONUCLEOTIDE PROBES}

Fluorescein-labeled oligonucleotides were synthesized and purified by Eurogentec (Seraing, Belgium).

To enumerate all Bacteria, the bacterial probe S-DBact-0338-a-A-18 (Bact338): 5'-GCTGCCTCCCGTAGGAGT (1) was used. For enumeration of the bifido- bacteria, the Bif164 probe was used: 5'-CATCCGGCATTACCACCC (14).

The design and validation of the Bif 164 probe has been described elsewhere (14).

\section{ENUMERATION OF BACTERIA BY FISH}

\section{Faecal Samples from Newborn Infants}

Before analysis, the samples were transferred and concentrated into $1,200 \mu \mathrm{l} 50 \%$ ethanol in PBS. Depending on the amount of cells in the sample, part of the ethanol/PBS stock (usually $20 \mu \mathrm{l}$ ) was hybridized with group-specific fluorescent 16S rRNA targeted oligonucleotide probes or stained with 4',6-diamidino2-phenylindole (DAPI) for total cell counts as described before (4). Subsequently, samples were washed and filtered onto $0.2 \mu \mathrm{m}$ GTTP polycarbonate filters (Millipore, Etten-Leur, The Netherlands), mounted in Vectashield ${ }^{\circledR}$ (Vector Lab., Burlingame, CA) on microscope slides and enumerated using epifluorescent microscopy. Ten to 25 fields with a total of about 300 positive cells were counted for each sample.

\section{Faecal Samples from Adult Volunteers}

Cells from $1.5 \mathrm{ml}$ of fixed suspension were washed twice in filtered PBS and resuspended in $300 \mu \mathrm{l} 50 \%$ $(\mathrm{v} / \mathrm{v})$ ethanol/PBS. The PBS:ethanol stocks were diluted 1:24 with $50^{\circ} \mathrm{C}$ hybridization buffer. The diluted cell suspensions ( $45 \mu \mathrm{l}$ aliquots) were added to $5 \mu \mathrm{l} 50 \mathrm{ng} /$ $\mu$ oligonucleotide probes and hybridized overnight at $50^{\circ} \mathrm{C}$. An aliquot of 5 to $50 \mu \mathrm{l}$ of this hybridized cell suspension was washed at $50^{\circ} \mathrm{C}$ for $30 \mathrm{~min}$ in $5 \mathrm{ml}$ wash solution (hybridization buffer without SDS) before being filtered onto $0.2 \mu \mathrm{m}$ GTTP polycarbonate filters (Millipore, Etten-Leur, The Netherlands). For total cell

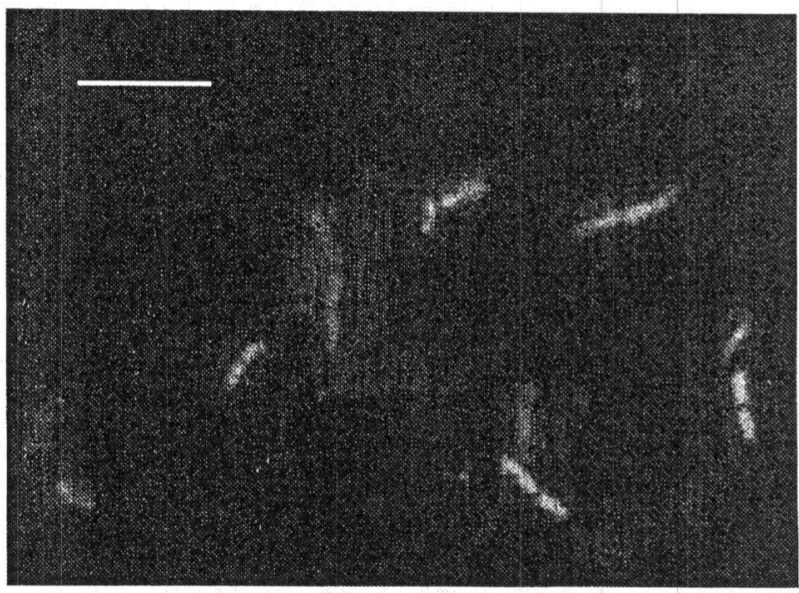

Fig. 1. Bifidobacteria in a faecal sample of a human volunteer detected with a FITC-labeled BIF164 probe. Scale bar, $5 \mu \mathrm{m}$. 
counts DAPI was added to the wash solution to a final concentration of $100 \mathrm{ng} / \mathrm{ml}$. Filters were mounted on clean microscope slides with Vectashield ${ }^{\circledR}$. Digital images of the slides, viewed with a Leica DMRXA epifluorescence microscope (Leica, Wetzlar, Germany), were taken with a Kodak Megaplus 1.4 CCD camera. An example of bifidobacteria in a faecal sample detected with the BIF164 probe is shown in Fig. 1. These images were analysed and fluorescent cells were counted using Quantimet HR600 image analysis software. Depending on the number of fluorescent cells, 10 to 30 microscopic fields were counted.

\section{Faecal Samples from Different Age Groups}

Faecal dilutions that had been fixed on the glass slides were hybridized with probes as follows. Probe dilutions $(50 \mathrm{ng} / \mu \mathrm{l})$ were made in Milli-Q and stored until use at $-20^{\circ} \mathrm{C}$. Prior to use they were further diluted in hybridization buffer of $50^{\circ} \mathrm{C}(20 \mathrm{~mm}$ Tris- $\mathrm{HCl}, 0.9 \mathrm{M} \mathrm{NaCl}$, $0.1 \%$ SDS, $\mathrm{pH} 7.2$ ) to a concentration of $10 \mathrm{ng} / \mu \mathrm{l}$. Slides were incubated with these probe dilutions for $16 \mathrm{hr}$ in a dark moist chamber at $50^{\circ} \mathrm{C}$. They were rinsed with hybridization buffer of $50^{\circ} \mathrm{C}$ for $30 \mathrm{~min}$. After briefly rinsing in Milli-Q, the slides were dried and mounted with $6 \mu$ l of Vectashield ${ }^{\circledR}$ on each well and a coverslip.

The slides were analyzed with an image analysis system consisting of a Quantimet 600HR-system, a Leica DM/RXA ultra-violet microscope equipped with a servo-controlled 8 slides-stage and a Kodak MegaPlus camera model 1.4. This system is connected to a second personal computer (Intelpentium $200 \mathrm{MHz}, 64 \mathrm{MB}$ RAM and 2.0 GB hard disk + Jazz-drive for datastorage) which is mainly used for analysis of the images obtained by the Quantimet 600 system. Twenty-five fields were counted automatically in each well. Coefficients of variation of these counts below 0.10 were considered to be an indication of homogeneous distribution of cells in the well.

\section{RESULTS AND DISCUSSION}

Over the past few years, we have used several protocols to enumerate bacterial populations in faecal samples. The flora development in newborn infants was studied with visual counting of fluorescent bacteria. Cells were collected on filters and this precludes autofocusing under phase-contrast illumination. To monitor variations in different bacterial groups in 9 adult volunteers we still collected the cells on filters. However enumeration was done with the Quantimet image analysis software. Further studies showed that we lost not more than $2 \%$ of the total number of cells when the fixed cells were applied to glass. Custom-made slides with 6 wells $(1 \times 1 \mathrm{~cm})$ were used for the next studies with samples from different age groups and this allows autofocusing under phase-contrast illumination and subsequent uv-illumination of the wells and automated counting of 25 fields in each well. Forty-eight faecal samples hybridized with one probe per sample can be processed overnight (12). Currently, miniaturization and more rapid autofocusing is investigated.

Figure 2 shows the development of bifidobacteria in faeces of 6 breast-fed babies measured with FISH. The relative numbers of the bacterial groups found in the samples are relative to the total number of cells counted

\section{Breast-fed infants}

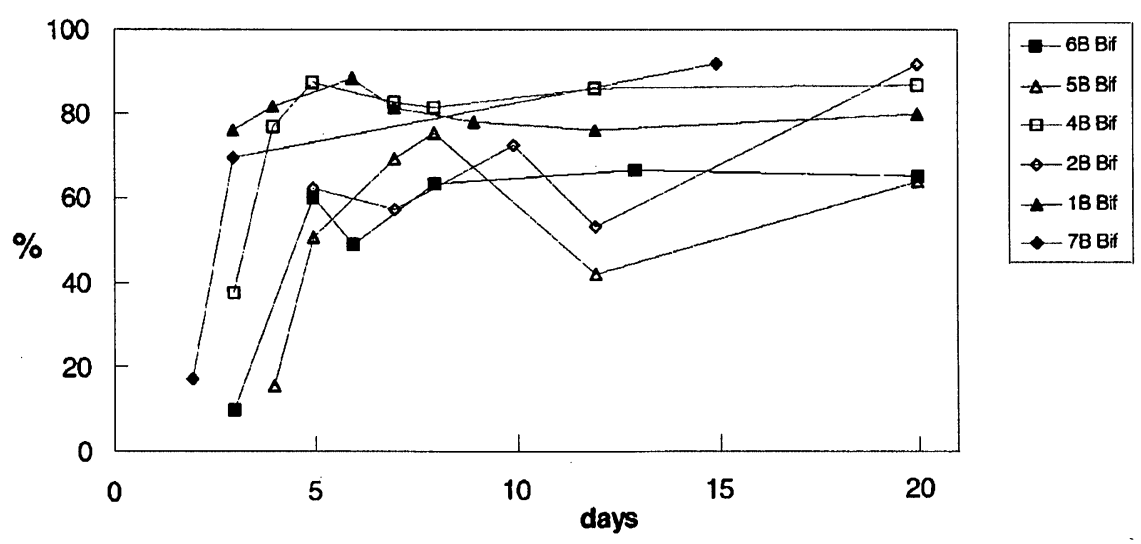

Fig. 2. Development of the bifidobacterial flora in the first 20 days after birth. Faecal samples of 6 breast-fed babies were analyzed with FISH. Probe Bif164 (14) was used to detect bifidobacteria. Total cell counts were obtained by DAPI-staining. The amount of bifidobacteria is given as percentage of the total number of cells. 


\section{Formula-fed infants}

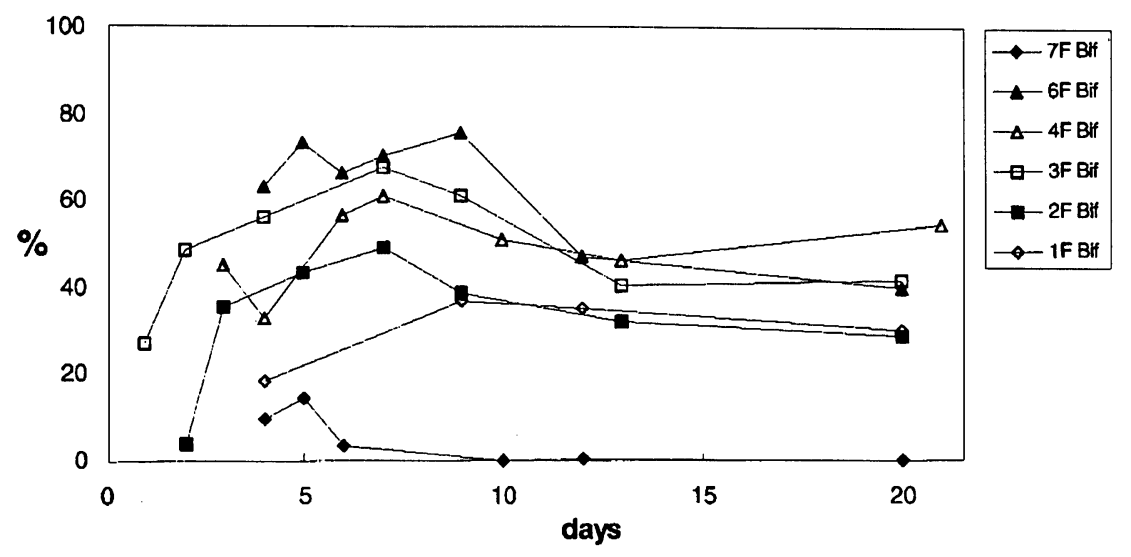

Fig. 3. Development of the bifidobacterial flora in the first 20 days after birth. Faecal samples of 6 formula-fed babies were analyzed with FISH. The infants received. The whey predominant infant formula Nutrilon Premium $^{\circledR}$ (Nutricia, Zoetermeer, The Netherlands). Probe Bif164 (14) was used to detect bifidobacteria. Total cell counts were obtained by DAPI-staining. The amount of bifidobacteria is given as percentage of the total number of cells.

after DAPI staining of the cells. DAPI stains all cells containing nucleic acid in the sample. In this case, the Bact338 probe which detects all bacteria was not used. During the first days of life, bifidobacterial numbers were below $40 \%$. But soon all bacterial flora's became dominated by bifidobacteria amounting to an average $78.9 \%$ of the total bacterial population and ranging from 62.9 to $91.0 \%$ of the flora on day 15 and 20 . Using other probes, we could also detect streptococci, E. coli and Bacteroides in some of the babies (10). Figure 3 shows the development of bifidobacteria in faecal samples from 6 formula-fed babies. The overall picture of bifidobacteria development is much more diverse and there are large differences in the number of bifidobacteria in the samples of individual babies. The average percentage bifidobacteria was $32.2 \%$ with a range from 0 to $54.1 \%$. Using other probes we can see that Bacteroides is present in higher numbers than in the samples from breast-fed babies $(10)$. Very striking is the virtual absence of bifidobacteria (less than $0.01 \%$ ) in one of the babies starting at day 10. Extremely low numbers of bifidobacteria were also seen in adults by Williams et al. (21). They studied the effect of adding a mixture of fructooligosaccharides to the diet on the human faecal flora. In two out of 10 volunteers the number of bifidobacteria was below the detection level $\left(10^{4} /\right.$ $\mathrm{g}$ of faeces) they used for culturing. To gain insight into the normal biological fluctuations in bacterial populations in faeces, we have monitored variations in the bacterial composition of the faecal flora of 9 adult volunteers (age 24-52 yr) with a set of 4 probes (4). For
Bacteroides a combination of the Bfra602, Bdis 656 probes was used. The Erec482 probe was used to detect the Clostridium coccoides-Eubacterium rectale group. The Bif164 probe and the Lowgc2P probe were used to quantify the bifidobacteria and the so far unculturable Low $\mathrm{G}+\mathrm{C} \# 2$ group (22), respectively. The Bact338 probe was used to detect all bacteria. The Bfra602/Bdis 656 probe combination detected $20.4 \%$ of the total population, and Erec 482 detected $28.9 \%$. The Lowgc2P probe detected $11.8 \%$ whilst Bif 164 detected only $3.4 \%$. Together, they accounted for $2 / 3$ of the total bacterial population. So far other probes only detect a minor part of the flora (less than $1 \%)(4,8)$ and there is a clear need for new probes that can detect the remainder of the bacterial flora. Figures $4 \mathrm{~A}$ and $\mathrm{B}$ show the variations in the bifidobacteria population over time. These volunteers were not on a restricted diet and thus the variations shown are those that commonly occur in a human population. The figure also shows that there are large individual differences. In some volunteers the bifidobacteria population stays at a relatively constant level (volunteers A, D and C) in others, large variations occur (e.g. E and G). Such differences should be taken into account when the effect of pro- and prebiotics is studied. We also compared the number of bifidobacteria as percentage of the total population in faecal samples from different age groups (Table 1). The average percentage bifidobacteria is $78.9 \%$ and $32.2 \%$ in breast-fed and formula-fed infants (age 15-21 days), respectively. Then there is a steady decrease to $13.3 \%$ in children of 2 and 3 years of age. In a group of adults 
Bifidobacteria in adult volunteers - A

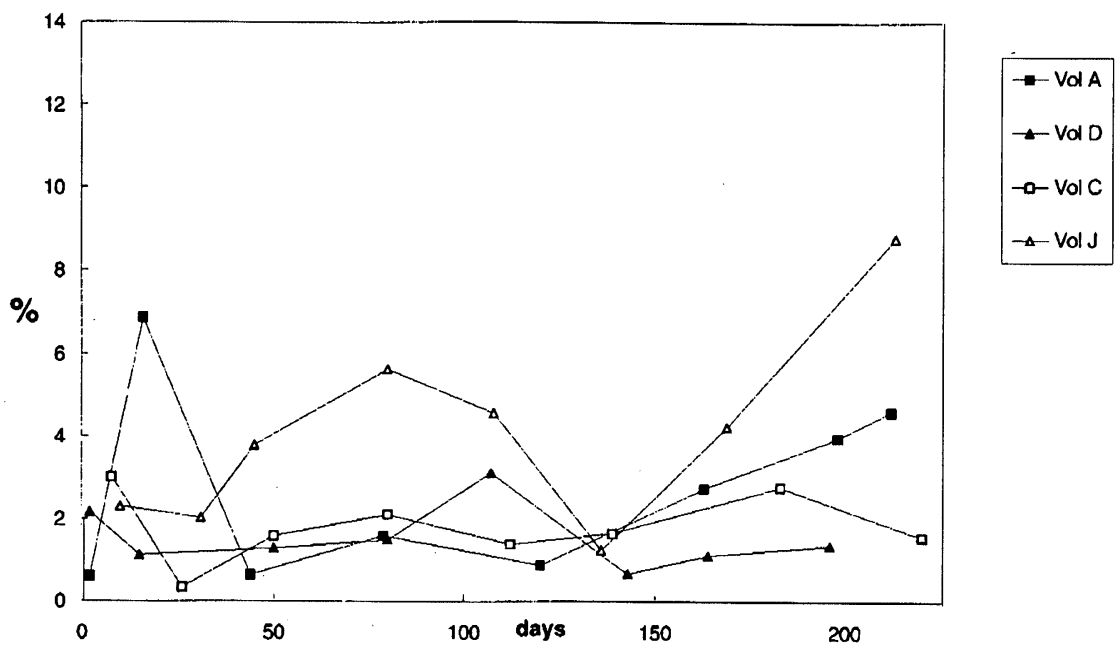

Bifidobacteria in adult volunteers - B

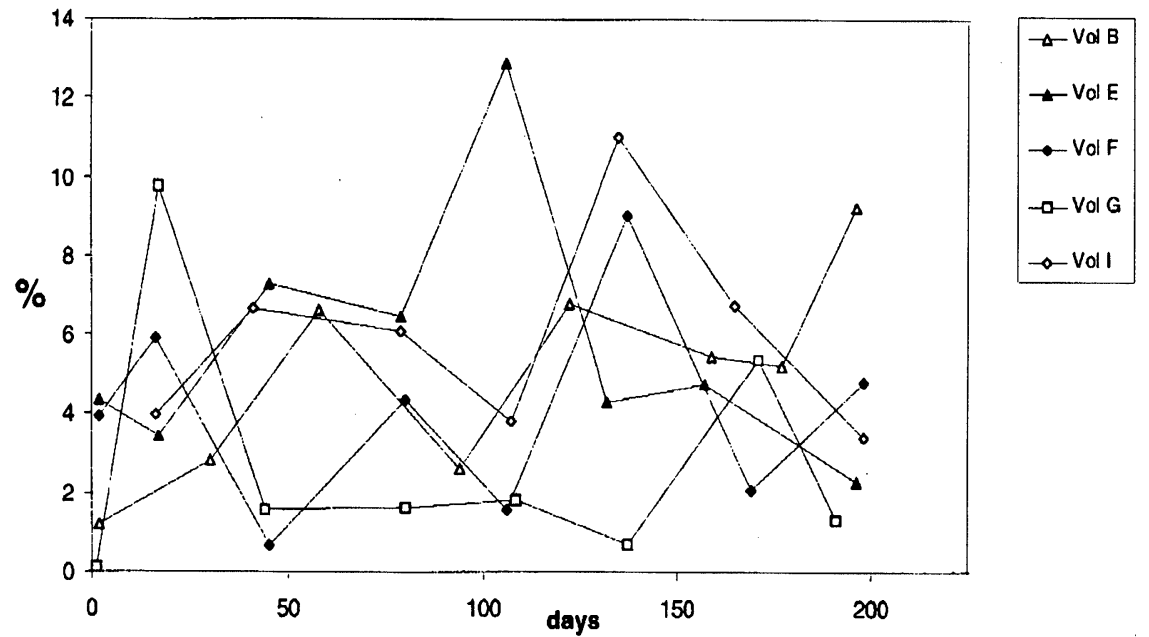

Fig. 4. Percentage bifidobacteria in 9 adult volunteers (age 24-52 yr) over a period of 200-220 days. Probe Bif164 (13) was used to detect bifidobacteria. Total cell counts were obtained by DAPI-staining. A) volunteers, especially A, C and D in whose faeces the level of bifidobacteria was relatively stable, B) volunteers in whose faecal samples the bifidobacteria showed relatively large fluctuations.

Table 1. Percentage of bifidobacteria in different age groups determined with FISH (the number of bacteria hybridizing with the Bact 338 probe is taken as $100 \%$ ).

\begin{tabular}{lrcc}
\hline & $n$ & Mean & Range \\
\hline Breast-fed infants (15-21 days) & 6 & 78.9 & $62.9-91.0$ \\
Formula-fed infants (15-21 days) & 6 & 32.2 & $0-54.1$ \\
Children (2-3 yr) & 12 & 13.3 & $4.3-27.0$ \\
Adults (20-52 yr) & 17 & 4.2 & $1.2-7.7$ \\
Elderly (77-91 yr) & 14 & 10.1 & $0.2-41.3$ \\
\hline
\end{tabular}

we found $4.2 \%$ bifidobacteria and in elderly we found that bifidobacteria constitute $10.1 \%$ of the total bacterial population in faeces. However individual differences in the latter group are extremely large, ranging from 0.2 to $41.3 \%$. It would be interesting to investigate the reasons for these differences and whether they are related to gastrointestinal motility, health status or diet.

In conclusion, the possibility to maintain a fixed diluted faecal sample at room temperature on a microscopic glass slide in a condition suitable for hybridiza- 
tion studies at a later time opens new possibilities for quantitative studies with regard to bacterial flora composition. Applying FISH with a defined collection of probes not only directed at bacteria in faeces, but also at samples from within the intestinal tract will help to refine our knowledge about the spatial distribution and dynamics of gut bacteria and their interaction with the host in health and disease.

Acknowledgments. This work was supported by grant 901-14-167 to GWW from the Netherlands Organization for Scientific Research (NWO) and by the European Commission (grant no. FAIR-CT97-3035).

\section{REFERENCES}

(1) Amann RI, Binder BJ, Olson RJ, Chrisholm SW, Devereux R, Stahl DA. 1990. Combination of 16S rRNA-targeted oligonucleotide probes with flow cytometry for analyzing mixed microbial populations. Appl Environ Microbiol 56: 1919-1925.

(2) Amann RI, Ludwig W, Schleifer K-H. 1995. Phylogenetic identification and in situ detection of individual microbial cells without cultivation. Microbiol Rev 59: 143-169.

(3) Finegold SM, Sutter VL, Mathisen GE. 1983. Normal indigenous intestinal flora. In Human Intestinal Microflora in Health and Disease, Hentges DJ (ed), Academic Press, New York, p. 3-31.

(4) Franks AH, Harmsen HJM, Raangs GC, Jansen GJ, Schut F, Welling GW. 1998. Variations of bacterial populations in human feces measured by fluorescent in situ hybridization with group-specific 16S rRNA-targeted oligonucleotide probes. Appl Environ Microbiol 64: 3336-3345.

(5) Gibson GR, Roberfroid MB. 1995. Dietary modulation of the human colonic microbiota: introducing the concept of prebiotics. J Nutr 125: 1401-1412.

(6) Giovannoni SJ, DeLong EF, Olsen GJ, Pace NR. 1988. Phylogenetic group-specific oligodeoxynucleotide probes for identification of single microbial cells. J Bacteriol 170: 720-726.

(7) Goldin BR, Gorbach SL. 1992. Probiotics for humans. In Probiotics. The Scientific Basis, Fuller R (ed), Chapman \& Hall, London, p. 355-376.

(8) Harmsen HJM, Elfferich P, Schut F, Welling GW. 1999. A $16 S$ rRNA-targeted probe for detection of lactobacilli and enterococci in faecal samples by fluorescent in situ hybridization. Microb Ecol Health Dis 11: 3-12.

(9) Harmsen HJM, Prieur D, Jeanthon C. 1997. Group-specific $16 \mathrm{~S}$ rRNA-targeted oligonucleotide probes to identify thermophilic bacteria in marine hydrothermal vents. Appl Environ Microbiol 63: 4061-4068.

(10) Harmsen HJM, Wildeboer-Veloo ACM, Raangs GC,
Wagendorp AA, Klijn N, Bindels JG, Welling GW. 2000. Analysis of intestinal flora development in breast-fed and formula-fed infants using molecular identification and detection methods. J Pediatr Gastroenterol Nutr 30: 61-67.

(11) Hill MJ. (ed). 1995. Role of Gut Bacteria in Human Toxicology and Pharmacology, Taylor and Francis Ltd., London.

(12) Jansen GJ, Wildeboer-Veloo ACM, Tonk RHJ, Franks AH, Welling GW. 1999. Development and validation of an automated, microscopy-based method for enumeration of groups of intestinal bacteria. J Microbiol Methods 37: 215221.

(13) Kimura K, McCartney AL, McConnell MA, Tannock GW. 1997. Analysis of fecal populations of bifidobacteria and lactobacilli and investigation of the immunological responses of their human hosts to the predominant strains. Appl Environ Microbiol 63: 3394-3398.

(14) Langendijk PS, Schut F, Jansen GJ, Raangs GC, Kamphuis GR, Wilkinson MHF, Welling GW. 1995. Quantitative fluorescence in situ hybridization of Bifidobacterium spp. with genus-specific $16 \mathrm{~S}$ rRNA-targeted probes and its application in fecal samples. Appl Environ Microbiol 61: 3069-3075.

(15) Manz W, Amann R, Ludwig W, Vancanneyt M, Schleifer K-H. 1996. Application of a suite of 16S rRNA-specific oligonucleotide probes designed to investigate bacteria of the phylum cytophaga-flavobacter-bacteroides in the natural environment. Microbiology 142: 1097-1106.

(16) Mitsuoka T, Kaneuchi C. 1977. Ecology of the bifidobacteria. Am J Clin Nutr 30: 1799-1810.

(17) Nelson GM, George SE. 1995. Comparison of media for selection and enumeration of mouse fecal flora populations. J Microbial Methods 22: 293-300.

(18) Noble WC, Wade WG. 1998. Propionibacterium, Bifidobacterium, Eubacterium and related organisms. In Topley and Wilson's Microbiology and Microbial Infections, Balows A, Duerden BI (eds), 9th ed, Arnold, London, p. 519-531.

(19) Stackebrandt E, Rainey FA. 1995. Partial and complete 16S rRNA sequences, their use in generation of $16 \mathrm{~S}$ rRNA phylogenetic trees and their implications in molecular ecological studies. In Microbial Ecology Manual, Akkermans ADL, van Elsas JD, de Bruin FJ (eds), Kluwer Acad Publ, Dordrecht, Part 3.1.1, p. 1-17.

(20) Vollaard EJ, Clasener HAL. 1994. Colonization resistance. Antimicrob Agents Chemother 38: 409-414.

(21) Williams CH, Witherly SA, Buddington RK. 1994. Influence of dietary neosugar on selected bacterial groups of the human faecal microbiota. Microb Ecol Health Dis 7: 91-97.

(22) Wilson KH, Blitchington RB. 1996. Human colonic biota studied by ribosomal DNA sequence analysis. Appl Environ Microbiol 62: 2273-2278. 